РОЗРОБЛЕННЯ ІННОВАЦІЙНИХ ДИДАКТИЧНИХ МАТЕРІАЛІВ ІЗ ІНФОРМАТИКИ ЗА ВИМОГАМИ НОВОЇ УКРАЇНСЬКОЇ ШКОЛИ

\title{
DEVELOPMENT OF INNOVATIVE DIDACTIC MATERIALS IN COMPUTER SCIENCE ACCORDING TO THE REQUIREMENTS OF THE NEW UKRAINIAN SCHOOL
}

\begin{abstract}
Статтю присвячено одній із актуальних проблем візуалізації навчального матеріалу, зокрема з інфрорматики, для кращого сприйняття учнями теоретичних і практичних аспектів наукового пізнання шляхом застосування інноваційних дидактичних матеріалів. Основою для прогресивного розвитку суспільства сьогодення $є$ інтелектуальний потенціал його населення. Саме тому сучасна освіта має орієнтуватися на супердинамічний розвиток інтелектуальних здібностей школярів. Інноваційна технологія передбачає прочес розроблення і методику застосування чогось нового або модернізаціі наявного задля мотивації школярів заглибитись у тему, розвивати пізнавальну активність, креативність, здатність узагальнювати матеріал, виокремлювати головне і будувати сюжет, налаштувати їх на вироблення розумної стратегії власного життя, свій профресійний творчий потенціал, який забезпечить конкурентоспроможність на ринку праці.
\end{abstract}

У статті розалянуто інноваційні дидактичні засоби та методику їх застосування на уроках інфрорматики за вимогами Нової української школи. У закладах загальної середньої освіти вчителі застосовують найрізноманітніші дидактичні матеріали, але учнів цікавить щось нове, сучасне, що спрямовуватиметься на розвиток їхнього творчого потенціалу, а також в аспекті їхніх зацікавлень і вподобань. До таких засобів ми віднесли шисррограми, ментальні карти і чисрові комікси. Важливо вчити учнів правильно застосовувати отримані знання, пошуков системи і цифррові джерела, які за умови критичного підходу стають невичерпним джерелом інсоормації. А їхня модернізація - то вже робота творчого вчителя, адже основною метою НУШ є розвиток особистості учня з урахуванням його персональних особистісних якостей. Педагог, застосовуючи свої вміння і знання, організовує освітній процес відповідно до особливостей класу, а не здобувачі освіти підкорюються стилю та освітній системі педагога.

Розроблення $і$ застосування інноваційних дидактичних матеріалів із інфрорматики $\epsilon$ важливим компонентом сучасної шкільної освіти. Сучасні реалії ставлять перед громадою величезну кількість нестандартних ситуацій. Тож ми маємо навчити учасників освітнього прочесу (учня, студента) тому, яким чином творчо підійти до вирішення проблем різного роду за допомогою творчих та інноваційних методів.

Ключові слова: Нова українська школа, дидактичні засоби, ииоррограми, ментальні карти, цифррові комікси.

The article is assigned to one of the topical problems of visualization of primary material, the creation of information science, for the shedding of theoretical and practical aspects of scientific knowledge by scholars, the establishment of innovative didactic materials. We are happy to educate people for super-dynamic development of the intellectual health of the schoolchildren. Innovative technology involves the process of developing and using something new, or modernization and refinement of existing to motivate students to delve into the topic, develop their cognitive activity, creativity, ability to summarize the material, highlight the main and build a plot, customize their production. life, their professional creativity, which will ensure competitiveness in the labor market.

In the article, the innovative didactic methodology was introduced in the informatics lessons for the requirements of the New Ukrainian School. In the pledges of the middle-class education of the reader, it is necessary to develop the most popular didactic materials, and in the future, it will be new, fortunate, and will be focused on the development of this kind of creative potential, as well as Before such things were introduced in ciphers, mental pictures and digital comics. It is important to read the scholars correctly to correct the information, to the system and to the digital data, which, in case of a critical approach, become an unacceptable information dashboard. And their modernization, then also the robot of a creative reader. And the main method of NUSH is the development of special features of learning from the development of personal specialties.

The development and storage of innovative didactic materials from informatics is an important component of modern school education. The same person is involved in the process of education: a student, a student, how to creatively go to the solution of the problem of a different kind by creative, innovative methods).

Key words: New Ukrainian school, didactic means of cipher text, mental maps, digital comics.
Постановка проблеми у загальному вигляді

Важливим кроком реформування загальної середньої освіти стала Концепція Нової української школи (НУШ), затверджена розпорядженням Кабінету Міністрів України від 14 грудня 2016 р. Основною ідеєю Концепції є всебічний розвиток, виховання і соціалізація особистості, яка була би здатна до успішної взаємодії із соціальним і природним середовищем. Отже, і вивчення курсу інфрорматики у закладах загальної середньої освіти має рухатися до освітньої мети і прагматичної діяльності учнів, а саме: засвоєння ними фундаментальних понять із інформатики, вироблення навичок обробки інформації із використанням сучасних IKT. Але звернімо увагу на те, що уроки інформатики носять переважно діяльнісний характер, налаштований на розроблення і перетворення об'єктів інорормації. Нагальною є потреба 
розвитку творчого мислення, креативного підходу як до викладання матеріалу вчителем, так і до розроблення проєктів учнями як підсумку вивченого за темою [1, с. 103].

Аналіз останніх досліджень і публікацій. Процес розроблення дидактичних матеріалів розкрито у працях багатьох науковців, таких як Н. Морзе, О. Барна, В. Вембер, О. Кузьмінська. Практичні рекомендації щодо застосування традиційних та інфрормаційно-комунікаційних технологій у навчанні розкривають І. Іванов, І. Фадєєва, Н. Прокопович.

Значна частина науковців і вчителів-методистів уважає, що унаочнення, систематизація і модернізація дидактичних матеріалів, інноваційний підхід разом із їхнім різноманіттям сприятиме розвитку творчого, критично мислячого та готового до самостійної діяльності учня.

Виділення невирішених раніше частин загальної проблеми. Під час вивчення інформатики у закладах загальної середньої освіти педагог повинен спонукати учня знайти і побачити різницю між уявленням про певний фракт (чи подію) та реальністю, тобто вчити творчо мислити. Таку можливість нам нададуть інноваційні дидактичні засоби, спрямовані саме на те, щоб навчити учнів не підганяти фракти під готові стереотипи або загальновідомі аксіоми, а перевіряти інформацію, шукати підтвердження, аналізувати; вчать не мудрувати та не франтазувати, створюючи якийсь уявно-штучний світ, ледь придатний для сприйняття, а вміти пояснити свою позицію, яка вкладається у сприйняття реального. Інноваційні дидактичні засоби одразу протиставляються поняттю шаблонності, а також, деякою мірою, налаштовують учнів шукати алогічність, несхожість, учать критично підходити до аналізу матеріалу.

Мета роботи - аналіз можливості розроблення і застосування інноваційних дидактичних матеріалів із інорорматики за вимогами Нової української школи.

\section{Виклад основного матеріалу.}

Бурхливий розвиток світової спільноти диктує важливість кардинальних змін у методиках навчання учнів, засобах і технологіях їхнього розроблення, а також упровадження в освітній процес. Ми повинні готувати школярів до тенденції мінливості світу, вчити швидко адаптуватися до реалій і бути конкурентоспроможними. А це неможливо без упровадження інноваційних технологій освіти, модернізації дидактичних матеріалів, спрямованих на індивідуальний підхід до учня. «Інноваційна технологія» у буквальному перекладі означає «майстерність, яка рухається до змін». Будь-що нове знаходить свою реалізацію через певну технологію, спосіб, метод. Попри те, що існує низка проблем, які не можна вирішити старими способами, є утруднення із упровадженням новацій.
Традиційні дидактичні матеріали навчання інформатики і технології їхнього застосування у сучасній школі є недієвими стосовно нового покоління учнів, покоління Z. Сучасні циорові діти мають низку характеристик, властивих лише їм:

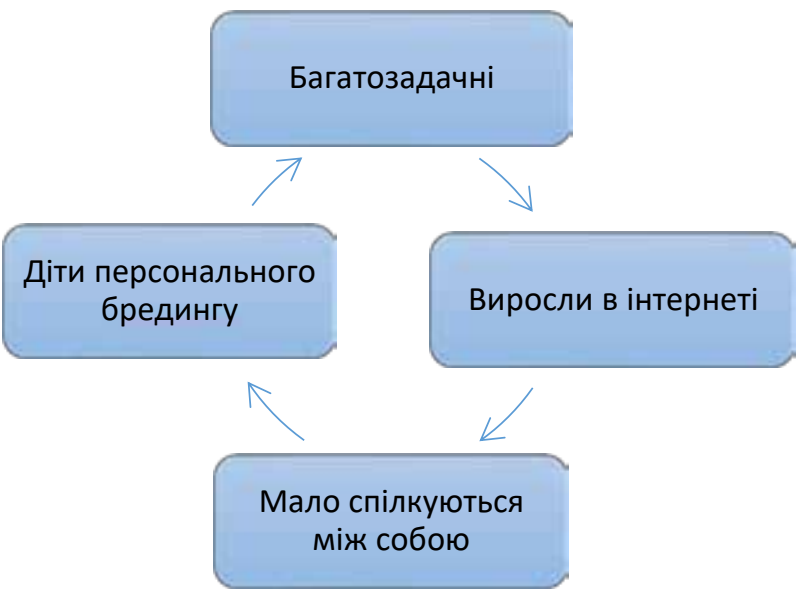

Сучасний педагог має оперувати цими характеристиками, розуміти, що запровадження інноваційних дидактичних матеріалів допомагає не лише його вихованцям ефективніше засвоювати матеріал, але і розвиває їхній творчий потенціал, критичне мислення, бажання відійти від шаблонності, адже рівень знання деяких цифрових технологій учнями може перевищувати рівень знань учителя. Розробка допомагає і вчителю реалізовувати власний інтелектуальний і творчий потенціал. У шкільній освіті застосовуються найрізноманітніші педагогічні інноваційні методики [2].

Одним із інноваційних дидактичних матеріалів $€$ шифрограми. Ця методика подання навчального матеріалу націлена на виникнення інтересу учня до матеріалу, що викладається на уроці, спонукає до уважності; вчитель не виступає лідером, а стає партнером і порадником. Школярі швидко налаштовуються на роботу, уявляючи себе супергероями, які мають перед собою певну місію, в нашому випадку - дешифрувати певний код, повідомлення тощо. Ми розглянемо на конкретних прикладах можливі варіанти.

Кодування Цезаря. Цей тип кодування використовується шляхом заміни літери на ту, яка зсунута на деякий ключ, наприклад на три літери вперед (рис. 1).

Спочатку ми пропонуємо учням просто декодувати термін, вислів, визначення. Надалі деякі завдання можуть подаватись у вигляді простого коду. Виконання цього завдання стимулюватиме пізнавальну активність і вміння концентрувати увагу.

Шифрування «Атбаш». Цей вид кодування $€$ заміною літери української абетки на протилежну (відповідно до розміщення). Наприклад, «ІНФОРМАЦІЯ» - «СЛЖКЇМЬЕСБ» (рис. 2). 


\begin{tabular}{|c|c|c|c|c|c|c|c|c|c|c|c|}
\hline Криптограма & $\mathbf{A}$ & Б & B & $\Gamma$ & 厂 & д & $\mathbf{E}$ & $\mathbf{E}$ & Ж & 3 & И \\
\hline Значення & Ю & Я & b & $\mathbf{A}$ & Б & B & $\Gamma$ & $\Gamma$ & Д & $\mathbf{E}$ & $\mathbf{E}$ \\
\hline Криптограма & I & $\ddot{I}$ & Й & $\mathbf{K}$ & Л & $\mathbf{M}$ & $\mathbf{H}$ & $\mathbf{O}$ & П & $\mathbf{P}$ & C \\
\hline Значення & Ж & 3 & И & I & $\ddot{\mathbf{I}}$ & Й & $\mathbf{K}$ & $\boldsymbol{\Omega}$ & $\mathbf{M}$ & $\mathbf{H}$ & $\mathbf{O}$ \\
\hline Криптограма & $\mathbf{T}$ & $\mathbf{y}$ & $\Phi$ & $\mathbf{X}$ & Ц & $\mathbf{Y}$ & Ш & Щ & Ю & Я & $\mathbf{b}$ \\
\hline Значення & П & $\mathbf{P}$ & $\mathbf{C}$ & $\mathbf{T}$ & $\mathbf{y}$ & $\Phi$ & $\mathbf{X}$ & Ц & $\mathbf{Y}$ & Ш & Щ \\
\hline
\end{tabular}

Рис 1. Кодування Цезаря

\begin{tabular}{|c|c|c|c|c|c|c|c|c|c|c|c|}
\hline Криптограма & $\mathbf{A}$ & Б & B & $\Gamma$ & I & Д & $\mathbf{E}$ & $\mathbf{E}$ & Ж & 3 & И \\
\hline Зна & $\mathbf{b}$ & Я & Ю & Щ & Ш & $\mathbf{U}$ & Ц & $\mathbf{X}$ & $\Phi$ & & $\mathbf{T}$ \\
\hline Криптогра & I & $\ddot{\mathbf{I}}$ & Й & $\mathbf{K}$ & $\pi$ & $M$ & $\mathbf{H}$ & 0 & П & & C \\
\hline Знач & C & $\mathbf{P}$ & П & $\mathbf{O}$ & H & $\mathbf{M}$ & $\boldsymbol{\Omega}$ & $\mathbf{K}$ & Й & & I \\
\hline Криптог & $\mathbf{T}$ & $\mathbf{y}$ & 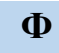 & $\mathbf{X}$ & 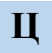 & $\mathbf{T}$ & r & r & Ю & & b \\
\hline Значення & И & 3 & Ж & $\mathbf{E}$ & $\mathbf{E}$ & Д & I & $\Gamma$ & B & & $\mathbf{A}$ \\
\hline
\end{tabular}

Рис. 2. Шифрування «Атбаш»

\begin{tabular}{|l|c|c|c|c|c|c|c|c|c|c|c|}
\hline Криптограма & $\mathbf{1}$ & $\mathbf{2}$ & $\mathbf{3}$ & $\mathbf{4}$ & $\mathbf{5}$ & $\mathbf{6}$ & $\mathbf{7}$ & $\mathbf{8}$ & $\mathbf{9}$ & $\mathbf{1 0}$ & $\mathbf{1 1}$ \\
\hline Значення & А & Б & В & Г & Г & Д & Е & С & Ж & 3 & И \\
\hline Криптограма & $\mathbf{1 2}$ & $\mathbf{1 3}$ & $\mathbf{1 4}$ & $\mathbf{1 5}$ & $\mathbf{1 6}$ & $\mathbf{1 7}$ & $\mathbf{1 8}$ & $\mathbf{1 9}$ & $\mathbf{2 0}$ & $\mathbf{2 1}$ & $\mathbf{2 2}$ \\
\hline Значення & І & Ї & Й & К & Л & М & Н & О & П & Р & С \\
\hline Криптограма & $\mathbf{2 3}$ & $\mathbf{2 4}$ & $\mathbf{2 5}$ & $\mathbf{2 6}$ & $\mathbf{2 7}$ & $\mathbf{2 8}$ & $\mathbf{2 9}$ & $\mathbf{3 0}$ & $\mathbf{3 1}$ & $\mathbf{3 2}$ & $\mathbf{3 3}$ \\
\hline Значення & $\mathbf{T}$ & $\mathbf{У}$ & $\mathbf{\Phi}$ & $\mathbf{X}$ & Ц & Ч & Ш & Щ & Ю & $\boldsymbol{Я}$ & Б \\
\hline
\end{tabular}

Рис. 3. Кодування «А1Ь33»

Цей спосіб кодування легший за шисрр Цезаря, оскільки передбачає лише гарне знання української абетки. Допомагає учням краще засвоїти не лише матеріал із інорорматики, але і налагоджує міжпредметний зв'язок із українською мовою, тому маємо подвійний позитивний результат.

Шифрування «A1Ь33». Зазначений тип криптування інсоомації (рис. 3) теж простий у застосуванні, оскільки у ньому передбачено елементарну заміну літери абетки на її порядковий номер. Наприклад, «ГРАФІКА»-«4 $2112512151 »$.

Шифррування за допомогою символів. Цей інноваційний метод активізації пізнавальної діяльності вчитель може розробити за власними вподобаннями. Головним принципом добору символів $€$ їхня унікальність і зрозумілість для учнів. Для прикладу, ми використаємо символи із Таблиці символів Microsoft Word. Один чи декілька символів надалі можуть бути невідомими для учнів та активізувати їхню дослідницьку активність

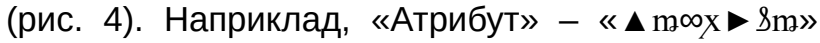
або «ПІКСЕЛЬ» - «£æ $\downarrow$ ८ $\odot \& ? »$

Наведені приклади кодування $є$ досить простими, тому учні швидко звикають до їхнього використання. Тому вчителеві доцільно час від часу змінювати спосіб кодування або застосовувати їхню комбінацію.

Для активних та сильніших учнів, які через декілька уроків легко будуть дешифрувати навчальний матеріал, учителеві варто розробити дидактичні картки із комбінацією декількох шисрів (два і більше). Наприклад, шляхом переведення цифр у літери (шифр А1Ь33), а потім декодувати літери із шифром «Атбаш», або ще додавши шифррування Цезаря (рис. 5).

Ігрові форми подання інформації $€$ одним із найбільш дієвих способів мотивації освітньої діяльності. Ми розглянемо ще один сучасний інноваційний дидактичний матеріал - цифровий комікс. Для уроків інформатики це $є$ незвичним, 


\begin{tabular}{|c|c|c|c|c|c|c|c|c|c|c|c|}
\hline Криптограма & $\Delta$ & $>$ & $\varphi$ & $\diamond$ & J & $\#$ & ;) & 棕 & $\mathbf{W}$ & D & $X$ \\
\hline Значення & $\mathbf{A}$ & Б & B & $\Gamma$ & I & Д & $\mathbf{E}$ & $\mathbf{E}$ & Ж & 3 & И \\
\hline Криптограма & $\mathbf{x}$ & $\Rightarrow$ & $€$ & $\checkmark$ & $\&$ & (a) & $\mathbf{A}$ & $\mathbf{P}$ & $£$ & $\infty$ & b \\
\hline Значення & I & $\ddot{\mathbf{I}}$ & $\check{\boldsymbol{И}}$ & $\mathbf{K}$ & $\boldsymbol{I}$ & $\mathbf{M}$ & $\mathbf{H}$ & $\mathbf{O}$ & $\Pi$ & $\mathbf{P}$ & $\mathbf{C}$ \\
\hline Криптограма & $\mathrm{m}$ & 8 & T & (C) & $\S$ & TM & ( & $\%$ & $*$ & $\wedge$ & $?$ \\
\hline Значення & $\mathbf{T}$ & $\mathbf{y}$ & $\Phi$ & $\mathbf{X}$ & Ц & $\mathbf{Y}$ & UI & Щ & Ю & Я & $\mathbf{b}$ \\
\hline
\end{tabular}

Рис. 4. Шифрування за допомогою символів

\begin{tabular}{|l|c|c|c|c|c|c|c|c|c|c|c|}
\hline Криптограма & $\mathbf{1}$ & $\mathbf{2}$ & $\mathbf{3}$ & $\mathbf{4}$ & $\mathbf{5}$ & $\mathbf{6}$ & $\mathbf{7}$ & $\mathbf{8}$ & $\mathbf{9}$ & $\mathbf{1 0}$ & $\mathbf{1 1}$ \\
\hline Значення & Щ & Ш & Ч & Ц & Х & Ф & У & Т & С & Р & П \\
\hline Криптограма & $\mathbf{1 2}$ & $\mathbf{1 3}$ & $\mathbf{1 4}$ & $\mathbf{1 5}$ & $\mathbf{1 6}$ & $\mathbf{1 7}$ & $\mathbf{1 8}$ & $\mathbf{1 9}$ & $\mathbf{2 0}$ & $\mathbf{2 1}$ & $\mathbf{2 2}$ \\
\hline Значення & О & Н & М & Л & К & Й & І & І & И & $\mathbf{3}$ & Ж \\
\hline Криптограма & $\mathbf{2 3}$ & $\mathbf{2 4}$ & $\mathbf{2 5}$ & $\mathbf{2 6}$ & $\mathbf{2 7}$ & $\mathbf{2 8}$ & $\mathbf{2 9}$ & $\mathbf{3 0}$ & $\mathbf{3 1}$ & $\mathbf{3 2}$ & $\mathbf{3 3}$ \\
\hline Значення & $\mathbf{C}$ & Е & Д & Г & Г & В & Б & А & Ю & Я & Б \\
\hline
\end{tabular}

Рис. 5. Комбінування шифрів

адже цей тип дидактичних матеріалів є різновидом методу сторітелінгу. Суть полягає в тому, що навчальний матеріал подається як дивовижна, вражаюча, приголомшлива історія, що слугує розвитку особистісно орієнтованих якостей, виставляє винятковість уяви кожного учня, сприятиме прояву креативності і творчості. Оскільки сучасні цифррові діти багато часу проводять онлайн, реальна комунікація стає проблемою, яку потрібно вирішувати. Для цієї мети прекрасно підходить метод «сторітелінга». Вчитель може залучити і учнів до розроблення цього виду дидактичних матеріалів, показавши їм, як, застосувавши прості безкоштовні інструменти або онлайн засоби, можна створити власний проєкт цифровий комікс. Цей продукт учні можуть презентувати у соціальних мережах, роздрукувати для власної колекції тощо. Завданням вчителя буде мотивувати учнів заглибитись у детальне вивчення теми, навчити виділяти головне, чітко продумати сюжетну лінію, а також активізувати пізнавальну активність і креативність. Зазвичай більшість учнів залучають власні емоджі-аватари як героїв власних коміксів. Це теж є проявом творчості. Вчитель має лише сприяти розвитку цифрової компетенції у реалізації їхніх запитів.

Одним із інноваційних методів є розроблення і застосування ментальних карт. Цей тип дидактичних матеріалів сприяє тому, щоб навчити учня вмінню виділяти головне, розробити структуру, зібрати воєдино різнорідні думки, виклавши їх за допомогою схеми. У цьому вчителю допоможе дієвий помічник - майндмепінг.
Ментальна карта (mind map) - це схема подання навчального матеріалу, яка має деревовидну структуру. Ядро - це головна, ключова тема, від неї гіллясто відходять складники (підтеми, підкатегорії одного або декількох порядків). Сама карта $€$ схематичною ілюстрацією основних компонентів вивчення теми, зав'язків між термінами, властивостями об'єктів теми, їхніми характеристиками тощо. У різних джерелах ментальні карти ще мають синоніми: карта знань, діаграма думок, інтелект-карта, ланцюг зав'язків. Розроблення інтелект-карт передбачає відображення стилю мислення автора, тому не має схожих між собою, вони можуть кардинально відрізнятися. Можна сміливо використовувати слова перебільшення (гіпер, мега), адже перебільшення краще сприймаються та запам'ятовуються [3]. Бажаним у розробці є гумор; карта має викликати емоцію, на хвилі якої вона запам'ятовуватиметься. Гумор має бути легким і йти на користь сприйняттю бажаної інформації.

Гарно оформлений матеріал карти притягує погляд учня і викликає пізнавальний інтерес, потрібні емоції та асоціації.

До розроблення ментальної карти за НУШ учитель залучає учнів, що є одним із методів візуалізації навчання (рис. 6). Спочатку ми пропонуємо зобразити схему на папері, у зошиті, а потім - попрацювати в одному із онлайн сервісів. Деякі з них мають стриманий дизайн, є лаконічними. До цієї категорії можна віднести Xmind, Diagrams, Mindmeister, Simple Mind, MindManager. Окрім того, існують онлайн засоби творчі і нестандартні, такі як Coggle, Ayoa, Mindmup, Mapul, Mindomo. Учитель може 


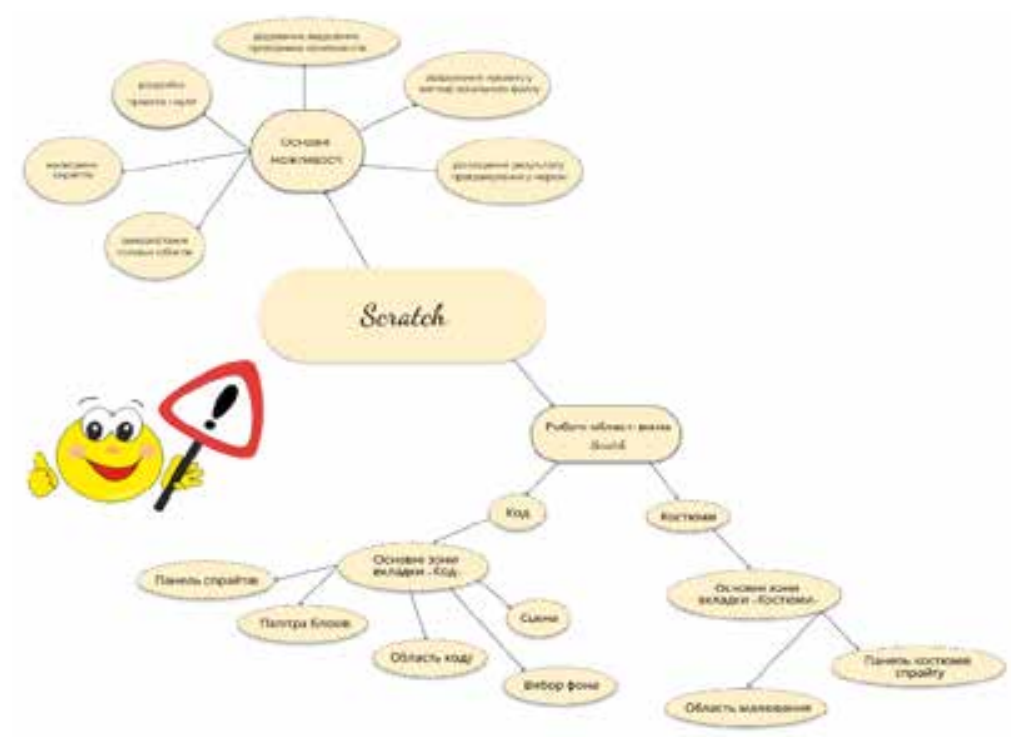

Рис. 6. Ментальна карта «Мова програмування Scretch. НУШ»

запропонувати учням проєкти ментальних карт. Оскільки в усіх сервісах передбачена командна робота та є підказки, як працювати з ними, спільна цікава і креативна співпраця гарантована.

Сучасні вчителі покликані зробити урок креативним, цікавим, пізнавальним, таким, що може розкрити потенціал учня, дозволить постійно підтримувати високий тонус дитячої уваги, навчить приймати самостійні рішення. Для цього і потрібно використовувати інноваційний дидактичний матеріал.

\section{БІБЛІОГРАФІЧНИЙ СПИСОК:}

1. Буйницька О.П. Інформаційні технології та технічні засоби навчання. Навч. посіб. Київ : Центр учбової літератури, 2012. С. 103-104.

2. Климина Н.В. Развитие операционального и креативного мышления учащихся на уроках информатики. URL. http://surl.li/aqhjc (дата звернення: 24.10.2021).

3. Паршукова Л.М. Розробка дидактичних і методичних засобів з інфрорматики. URL. http://dspace. udpu.org.ua:8080/jspui/handle/6789/2764 дата звернення: 25.10.2021). 